\title{
Orlando Charnock Bradley, M.D., D.Sc., F.R.C.V.S.
}

Orlando ChaRnock BRAdley was born at Wheelton, near Chorley, in Lancashire, on May 8, 1871 .

He received his early education at Wheelton, afterwards proceeding to Chorley Grammar School. Later he attended classes in chemistry, animal physiology and botany at the Harris Institute, Preston, before entering the New Veterinary College, Edinburgh, which was then carried on as a private enterprise by the late Professor William Williams, but was afterwards incorporated by the University of Liverpool in which it now forms the School of Veterinary Science. Bradley's student career was such that his outstanding ability quickly attracted the attention of Williams, and upon his graduating M.R.C.V.S. in 1892 he was at once appointed Lecturer in Comparative Anatomy and in addition was placed in charge of the College Hospital. It cannot be said that his bent ever lay towards clinical veterinary practice, and one may venture to assume that he did not find his hospital duties particularly attractive, especially when they had to be undertaken in conjunction with his studies in comparative anatomy, in which subject, from his first contact with it, he knew he had found his true scientific sphere. It was nevertheless in the field of clinical veterinary medicine that the spirit of inquiry and the faculty of precise observation which he possessed, and in later years so markedly developed, first became evident in a published paper, for it was at this early stage that he recorded his observations on the treatment of intestinal tympany in the horse by antizymotic agents introduced directly into the colon by intestinal puncture.

By reason of temperament and inclination Bradley soon became almost wholly immersed in his anatomical work, and in order (among other reasons) to extend his knowledge of comparative anatomy took up the study of medicine at the University of Edinburgh, where he graduated M.B., Ch.B., in 1900. He was Goodsir Memorial Fellow in the years 1903-5, the title of his thesis being The Comparative Anatomy of the Mammalian Cerebellum, and in 1905 was awarded the degree of Doctor of Science in respect of his work on the development and morphology of the mammalian hind-brain. Two years later there followed the conferment of his Doctorate in Medicine for his researches in the development of the mammalian liver, and in 1908 he received from 
the Royal College of Veterinary Surgeons the John Henry Steel Memorial Medal "in reward of merit."

Between I 893 and I908 Bradley's contribution to the literature was extensive and during this period he published forty-seven original scientific communications, principally on anatomical, genetical and historical subjects. His text-books have proved of incalculable value to veterinary science. The Outlines of Veterinary Anatomy published in three parts in 1896-97 was an immature effort in which he, in after years, found no satisfaction, but his later works were wholly admirable and have become standard texts. These are: Topographical Anatomy of the Limbs of the Horse (1920); Topographical Anatomy of the Thorax and Abdomen of the Horse (1922); Topographical Anatomy of the Head and Neck of the Horse (1923); Topographical Anatomy of the Dog, in three editions (1919, 1927, 1935); and The Structure of the Fowl, in two editions ( 1915,1937 ).

He founded and was editor of the excellent but short-lived Veterinary Review (I9I7-20), which had as its object the provision of an account of current veterinary literature of interest to the specialist and the practitioner.

In his scientific writings Bradley's diction is simple, clean-cut and explicit, but on occasion he would write, as he would often speak, with grace and charm. His History of the Edinburgh Veterinary College, published on the occasion of the centenary of the College in 1923, is not only an authoritative historical record but a fascinating tale.

In October I900 he was elected to the Chair of Anatomy in the Royal (Dick) Veterinary College and to the Principalship of the College in I9I I, in which year he was also appointed to the Barclay and Goodsir Lectureship in Comparative Anatomy in the University of Edinburgh. In the same year he was elected to the Council of the Royal College of Veterinary Surgeons, the governing body of the veterinary profession.

This time not only marked an epoch in Bradley's career, but the circumstances of it effected a widening of his sphere of influence and occasioned a redirection of the main lines of his activities. His research work gave place to administration not only in that which concerned his College, but in the wider field of professional politics. His wisdom in council was early recognised by his being elected Vice-President of the Royal College in 1912, and again in I919, before proceeding to the Presidential Chair, which he occupied from 1920 to 1922 . In I935 he received the highest honour which it is within the power of the Royal College to bestow-that of Honorary Fellowship.

In Igog Bradley in a presidential address to the Scottish Metropolitan 
Veterinary Medical Society outlined his conception of uniting all the many veterinary societies scattered throughout the country into one national association. At a conference held the following year the principle of amalgamation was approved, and a committee under Bradley's chairmanship was appointed to advance the scheme. After years of labour and in face of much discouragement, approval and acceptance of the constitution and rules of that body now known as the National Veterinary Medical Association of Great Britain and Ireland were finally obtained. Bradley was first elected President in I9I4 and served as President continuously until 1922.

The Board of Management of the Royal (Dick) Veterinary College as early as 1907 recognised the need for the removal of the College to new and much more commodious buildings, but because of numerous difficulties and delays the actual building of the new College in Summerhall was not begun till I9I3, and its memorial foundation-stone was laid two days before the outbreak of the Great War. The lean years of the war constituted a period during which his dominant qualities, quiet steadfastness to purpose and unswerving determination were most clearly evident. Not only did he find ways and means of carrying on the building of the fabric of the new College in spite of the diminution in the building funds due to the rapidly rising costs, but maintained, at least in being, the National Veterinary Association which almost from its inception he had to guide with a steady hand along the very edge of financial bankruptcy. The fine buildings in which the Edinburgh Veterinary College is now housed and the strength to which the National Veterinary Association has so rapidly attained must have been causes of much satisfaction.

His interest in general scientific matters is reflected in his long association with the Royal Physical Society of Edinburgh, to the Fellowship of which he was elected in I893, serving as Secretary I903-II and as President 1912-I5. Between I90I and 1928 he made twelve contributions to the Society's Proceedings.

Bradley was elected a Fellow of the Royal Society of Edinburgh in 1903. He was a member of the Council, 1907-10 and again 1915-17, and served as Vice-President 1934-37. Two of his papers are published in the Society's Proceedings: "Abdominal Viscera of Cercocebus fuliginosus and Lagothrix humboldti (1903), and "Craniometrical Observations on the Skull of Equus prjevalskii and other Horses" (1907).

Bradley could upon occasion affect a charming geniality, but his natural manner was placid, suave, precise and even cold. His sense of humour was deep and very real, but his wit, while nimble and adroit, could be sharp. His tastes were artistic and blended curiously but 
smoothly with his scientific attributes. He performed with acceptance upon the violoncello and appreciated music very warmly; yet, with complete detachment, he could informedly discourse upon the mechanism of its production. He was readily touched by natural beauty, especially the beauty of flowers, and this but served to quicken his interest in the principles and practice of scientific plant-breeding. It was in the possession of so many and such different qualities and of a mind so keen, cultured, and so severally faceted that Bradley was equipped splendidly for carrying through the many important tasks which he sought and to which he set himself. The passage of time alone will permit of the proper assessment of the remarkable contribution he made to the advancement of Veterinary Science during, perhaps, the most critical phase of its development.

He died on November 2 I, 1937.

J. R. G. 